\title{
Ramírez García, Tania Jesús. Traducción de la metáfora poética desde un enfoque comunicativo: metáfora Iorquiana. Las Palmas de Gran Canaria: Universidad de Las Palmas de Gran Canaria, Servicio de Publicaciones- Fundación Mapfre Guanarteme. 2009. 131 pp. ISBN 978- 8492777372.
}

Bajo el título Traducción de la metáfora poética desde un enfoque comunicativo: metáfora lorquiana, la autora, Tania Jesús Ramírez, pone el foco de atención sobre la metáfora poética y nos ayuda a adentrarnos en sus peculiaridades lingüísticas, culturales y traductivas. Este estudio inductivo se encuentra dividido en cinco capítulos, en los que se hace un barrido teórico sobre las reflexiones de otros autores que han plasmado sus ideas sobre la temática que aquí nos trae, tratando de rellenar los huecos metodológicoteóricos encontrados por el camino para proceder a un análisis exhaustivo de los versos de Lorca y arrojar luz sobre el trasvase cultural tanto de su obra como de la metáfora en general.

Como introducción, reflexiona sin extenderse sobre la importancia del traductor como mediador en la comunicación intercultural, nos recuerda que la función principal del traductor es crear un texto comunicativamente equivalente, teniendo en cuenta factores como su conocimiento del tema y el autor, la metodología de creación del mismo, el receptor del TM, así como otras circunstancias que puedan resultar pertinentes a la hora de afrontar un encargo traductor de tal ardua índole.

Ya de lleno en cuestiones teóricas, en el primer capítulo titulado "Algunos problemas de la actividad traductora", pasa a la exposición de la importancia y génesis de los problemas de la traducción de referentes culturales. Recurre a los textos de Vinay y Darbelnet, Nida y Taber, Reiss y Vermeer, Klingberg y Newmark. Se muestra de acuerdo con sus aportaciones de forma parcial; cuando hace una pequeña crítica, nos ofrece sus aportaciones complementarias desde el punto de vista comunicativo. A su vez, hace hincapié en lo crucial del conocimiento de las normas del comportamiento verbal y el simbolismo propio de cada pueblo, ya que es ahí donde no se recurre a ideas universales que el traductor encontrará escollos durante su trabajo. Cierra el capítulo apostando por la adaptación como estrategia de traducción en estos casos, entendiéndola en su doble acepción, tanto aquella necesaria para la comprensión y aceptación de un TO en la cultura de llegada, como aquella que se da y que modifica el mapa conceptual 
original, sirviéndose del ejemplo recurrente de la adaptación de los clásicos para niños.

En el segundo capítulo, "Rasgos del texto poético para la traducción", pasa a indagar la relevancia de la forma y el contenido metafórico, el peso del sistema métrico y los patrones de rima en poesía, las repeticiones en todos los planos textuales y se extiende en la exposición de Goncharenko (1980), quien postula una división dual del poema con subdivisiones internas. Trasladando estos acercamientos teóricos del texto poético a la metáfora, recupera las teorías de Dagut, Newmark, Mason y Snell-Hornby para evidenciar la ausencia del contenido comunicativo en sus teorías. Esto nos conduce a las posibilidades que tiene el traductor para trasvasar el contenido metafórico a otra lengua - que en este caso serían: utilizar un equivalente metafórico, crear una metáfora nueva, dejar atrás la metáfora sin alterar el significado del texto o que la metáfora sea interpretada de manera errónea por el traductor- teniendo en cuenta las nociones culturales que tenga el público meta de la cultura de partida.

Dejando a un lado el completo del poema para centrar el foco de mira en la metáfora, en "Enfoque de la metáfora poética desde la teoría del sentido", esclarece su postura ante la definición del 'sentido', compuesto por una jerarquía estructural, explicada con todo detalle, entre la situación comunicativa, la pragmática y la semántica. Para que la traducción se haga de forma adecuada, apuesta por la necesidad el conocimiento profundo de la autora o autor en cuestión, así como su personalidad y contexto para llegar a la intencionalidad de la que nace el texto. Esta declaración de intenciones, mantiene Tania Jesús Ramírez, también se recoge en las metáforas presentes en un poema e influyen en el programa conceptual del mismo. Siguiendo con la pertinencia de las teorías comunicativas de la traducción, la jerarquía también se extrapola a las intenciones del texto, concluyendo, de forma bastante acertada, con que el éxito de la comunicación (en este caso intercultural, a través de la traducción) se encuentra intrínsecamente ligado a las competencias del comportamiento verbal y contexto extralingüísticos de la cultura original por el receptor en la lengua meta.

Abriendo paso al estudio empírico en el cuarto capítulo, en cuyo título, "Evaluación de la traducción de algunas metáforas culturales del Romancero gitano" se presenta la intención principal de este apartado, para el que toma como corpus de trabajo las distintas traducciones del poemario de Federico García Lorca. Con el fin de facilitar la comprensión del texto original al lector, nos ofrece documentación sobre la vida del granadino, el contexto histórico, político y literario en el que desarrolló su obra; por otro lado, y con una extensión que demuestra una amplia labor de investigación, nos presenta las biodatas de los traductores responsables de las distintas versiones en lengua 
inglesa. La metodología de trabajo también queda desglosada al detalle: en primer lugar, precisa la importancia de las diferencias culturales dentro de una misma lengua - Reino Unido, Estados Unidos y Canadá-; en segundo, divide las metáforas poéticas en dos categorías: existen metáforas basadas en conceptos universales, que dada su universalidad, no presenta un reto o dificultad para el traductor y metáforas basadas en conceptos o elementos culturales (esta categoría es la imperante en la obra de lorquiana). Ordenados según aparición en el poemario, los poemas "Preciosa y aire", "Reyerta", "Romance sonámbulo", "San Miguel.Granada", San Gabriel. Sevilla", "Prendimiento de Antoñito el Camborio en el camino de Sevilla", "Muerte de Antoñito el Camborio", "El emplazado" y "Romance de la Guardia Civil española" pasan a desnudarse en el análisis siguiendo estos pasos: un comentario filológico sobre las figuras y la carga metafórica para llegar a la intención del autor, un análisis traductológico agrupando las distintas traducciones por cultura y finalmente una propuesta de traducción que no pretende, en palabras de la autora, imponerse a la existente sino complementarlas.

El último capítulo que sirve como conclusión y análisis de los resultados, resume las ideas que ya habían ido quedando explícitas a lo largo de los capítulos anteriores y brinda datos estadísticos en forma de porcentajes de los resultados arrojados por el estudio, que evidencian, una vez más, la necesidad de un conocimiento de las normas de comportamiento de la cultura del autor, los hechos históricos, ideológicos y sociales, tradiciones e incluso fauna y flora local. Pone el broche final a su trabajo abogando por el estudio contrastivo entre textos originales y su traducción como vía de investigación para conseguir arrojar luz en el trasvase interlingüístico de la metáfora.

La genialidad de este volumen reside, junto al buen desarrollo científico-metodológico del mismo, en su pertinencia. Pese a la distancia temporal con su publicación, el arrastre de la poca atención que la traducción de la metáfora sufre en la Traductología desde sus comienzos, e incluso antes de su independencia en su posición dentro de la Lingüística aplicada, no se ha profundizado mucho más en el tema. Acercar la metáfora a las teorías comunicativas de la Lingüística nos parece todo un acierto, casi lógico. No podemos olvidar que al traducir un texto estamos ayudando a que, derribadas las barreras lingüísticas, un acto de comunicación sea posible. Algo que podría considerarse evidente parece pasar desapercibido en la traducción literaria con una frecuencia mayor de la que pudiéramos pensar, incluso por parte de grandes estudiosos de la traducción. Dar prioridad máxima a los elementos que hacen posible que una comunicación funcione, estudiarlos y tenerlos en cuenta en la elección de técnicas y estrategias de 
traducción, es una competencia traductora básica. De igual modo, es aplaudible, dentro del conjunto de la monografía, la división por culturas de los textos que conforman el corpus, ya que, como ella misma afirma, las lenguas superan fronteras y es necesario prestar atención a lo que tenemos en nuestro entorno antes de elegir un término u otro. La variedad diatópica, que tanto se tiene en cuenta en otras modalidades de traducción (localización de software y videojuegos, traducción multimedia, etc.), tiene el mismo peso en la Literatura.

El trabajo de Tania Jesús Ramírez García nos ayuda a digerir el hermetismo propio de la poesía y acercarnos más a ella. Los avances recogidos en este libro pueden sentar las bases de futuros estudios en torno a la traducción poética en general o al trasvase de los tropos en contextos particulares, sin obviar que este trabajo se postula como un recurso didáctico idóneo para la formación de traductores universitarios.

[Víctor ANGUITA MARTíNEZ] 